\title{
Pedagógusok élettel való elégedettsége és összefüggése a kiégéssel, valamint a pszichoszomatikus egészség mutatóival
}

\author{
MIHÁLKA MÁRIA - PIKÓ BETTINA²* \\ ${ }^{1}$ Szegedi Tudományegyetem, Neveléstudományi Doktori Iskola és Egészségtudományi \\ és Szociális Képzési Kar, Szociális Munka és Szociálpolitika Tanszék, Szeged \\ ${ }^{2}$ Szegedi Tudományegyetem, Általános Orvostudományi Kar, \\ Magatartástudományi Intézet, Szeged
}

(Beérkezett: 2018. január 4.; elfogadva: 2018. március 20.)

\begin{abstract}
Elméleti háttér: A pedagógushivatás a leginkább stresszel telített foglalkozások között található, még a segítő hivatásúakat tekintve is. A kiégés tünetegyüttes előfordulása gyakori a pedagógusok között, amely nagy kihívást jelent, mivel számos negatív következménye lehet, mint az egészségügyi problémák, pl. a depresszió, és a munkával való elégedetlenség. Cél: Jelen tanulmány célja az volt, hogy a kiégés és egyéb az egészséggel összefüggő jelenség (pl. pszichoszomatikus tünetek, egészségmagatartás, egészség önértékelése) szerepét vizsgáljuk a magyar pedagógusok élettel való elégedettségében, amely a szubjektív jóllét egyik mutatója. Módszer: Az adatgyújtés magyar pedagógusok $(n=2068$, 23-74 év közöttiek, átlagéletkor $=48,1$ év, SD = 8,9 év; 83,5\%-uk nő) körében történt 20162017 között. A kiégés mérése a Maslach Kiégés Kérdőív pedagógus változatának segítségével történt. A kérdőív tartalmazott kérdéseket az élettel való elégedettségről, a pszichoszomatikus tünetekről és egyéb, egészséggel kapcsolatos témakörökről. Eredmények: Az adatok megerősítették, hogy a kiégés létező probléma a magyar pedagógusok körében. Különösen a fiatal és férfi pedagógusok vannak veszélyben, ami azzal magyarázható, hogy nem rendelkeznek megfelelő rutinnal e problémák megoldásához. A kiégés alskálái közül a teljesítménycsökkenés $(\beta=-0,21 ; p<0,001)$, és az érzelmi kimerültség $(\beta=-0,18$; $p<0,001)$ játszanak szerepet az élettel való elégedettségben. Az élettel való elégedettség szintén összefüggést mutatott a pszichoszomatikus tünetekkel $(\beta=-0,14 ; p<0,001)$ és a saját egészség értékelésével $(\beta=0,12 ; p<0,001)$. Az egészséggel kapcsolatos változók tehát hozzájárultak az élettel való elégedettséghez is. Következtetések: Az eredmények azt mutatják, hogy a kiégés megelőzéséhez nagy szükség lenne intervenciós programokra mind egyéni, mind pedig szervezeti szinten.
\end{abstract}

Kulcsszavak: kiégés, élettel való elégedettség, pedagógusok, egészségmagatartás, pszichoszomatikus tünetek

\footnotetext{
* Levelező szerző: Prof. Dr. Pikó Bettina, Szegedi Tudományegyetem, Általános Orvostudományi Kar, Magatartástudományi Intézet, 6722 Szeged, Szentháromság u. 5. E-mail: fuzne.piko.bettina@ med.u-szeged.hu
} 


\section{Bevezetés}

A segítók lelki egészsége nem tekinthetó magánügynek: a segítők viselkedésükkel mintát nyújtanak azoknak a klienseknek, pácienseknek, gondozottaknak, tanítványoknak, akiket segítenek, ápolnak, gondoznak, nevelnek, oktatnak. Ugyanakkor a hivatásukat jelentő lelki és olykor fizikai teher nyomot hagy saját lelki egészségükön. Ennek egyik megnyilvánulása a kiégés jelensége. A pedagógusok, mint segítő hivatást gyakorlók igen gyakran ki vannak téve a kiégés veszélyének, ami befolyásolja testi és lelki egészségüket, munkateljesítményüket, élettel való elégedettségüket (Hakanen, Bakker, \& Schaufeli, 2006).

A kiégés (burnout) fogalmát a pszichológia 1974 óta használja, elsőként az amerikai származású pszichoanalitikus, Herbert Freudenberger alkalmazta. A kiégést Freudenberger a következóképpen fogalmazta meg: „A szindróma krónikus, emocionális megterhelések, stresszek nyomán fellépó fizikai, emocionális, mentális kimerülés állapota, mely a reménytelenség és inkompetencia érzésével, célok és ideálok elvesztésével jár, s melyet a saját személyre, munkára, illetve másokra vonatkozó negatív attitúdök jellemeznek" (Fekete, 1991, 17. o.). A fogalom meghatározásakor elsősorban az okokra és a látható, érzékelhető tünetekre koncentrál Freudenberger, mint a cinizmus, a boldogtalanság, az unalom, különböző pszichoszomatikus tünetek és krónikus fáradtság (Bordás, 2010).

Maslach és Jackson (1982) fogalmi meghatározása eltér Freudenbergerétől: a kiégést komplex szociális kontextusba ágyazott, a személyiség másokkal, valamint magával szembeni attitúdjével kapcsolatos jelenségként definiálja. A kiégés jelenségének három dimenzióját írták le: az emocionális kimerültséget, a deperszonalizációt, valamint a teljesítménycsökkenést. A szakirodalom alapján úgy foglalhatjuk össze, hogy a kiégés, elhúzódó érzelmi megterhelés és stressz hatására kialakuló érzelmi, mentális és fizikális kimerülés, amely során társas interakcióikban az egyének nem képesek reálisan megítélni sem önmaguk, sem pedig a környezetükben lévő személyek viselkedését, teljesítményét. Ennek következtében gyakori a negatív önértékelés, és a környezetnek a valóságnál negatívabb észlelése. A munkához kapcsolódó célok leértékelódnek, a munkavégzés öröme, és az alkotó lelkesedés eltünik. Mindez együtt jár azzal, hogy sérül az egyén megküzdési képessége (Mihálka, 2015).

A kiégés tárgykörével foglalkozó első kutatások célja az 1970-es években az volt, hogy leírják magát a jelenséget. Később a kutatásokban két irányvonal alakult ki: az egyik arra koncentrált, hogy milyen hajlamosító tényezők lehetnek a személyiségjegyek szintjén, illetve, hogy milyen tünetei vannak a jelenségnek, míg a másik a munkahely, a társas környezet, a segítő és segítséget kérő közötti kapcsolat, valamint a munka, illetve a szervezet jellegzetességeit helyezte előtérbe, mint pl. a munkahelyi stressz (Kovács, 2006). 
Ehhez kapcsolódik az a kutatási irány, amely kezdettól fogva jelen volt, már a jelenség leírásánál: a kiégés egészségre és életminőségre gyakorolt hatásainak vizsgálata (Cazan \& Năstasă, 2015). Itt természetesen figyelembe kell venni az ok-okozati kapcsolatok bonyolultságát: bizonyos pszichés zavarok (pl. depresszió, szorongás) vagy akár krónikus betegségek (pl. magasvérnyomás) eleve hajlamosíthatnak a kiégés kialakulására (Zinchenko, Pervichko, \& Ostroumova, 2016), ugyanakkor a kiégés következtében is nagyon sok egészségügyi problémával kell számolnunk az egészségmagatartásbeli változásoktól (dohányzás, alkoholfogyasztás, stb.) kezdve a pszichoszomatikus tüneteken át a klinikai kórképek megjelenéséig (Leiter, Bakker, \& Maslach, 2014). E betegségek főként a stressz okozta élettani változások következtében jelennek meg (Grossi, Perski, Eventgård, Blomkvist, \& OrthGomér, 2003). Ennélfogva a pszichoszomatikus tünetek lényegében stresszindikátorok, és előrejelzői a súlyosabb kórképek megjelenésének (Pikó, 2003). Montgomery és munkatársai (2005) egy dél-afrikai vizsgálatban igazolták a kiégés testi és lelki betegségekhez vezető szerepét, ami összefüggött a munkahelyi környezettel, az erőforrások (pl. társas támogatás, lehetőségek a fejlődésre) és az akadályozó tényezók (pl. szerep- és kommunikációs zavarok) arányaival. Nem meglepó, hogy a munkahelyi stressz levezetésére sokan alkalmaznak valamilyen kémiai anyagot tartalmazó szert, így a dohányzás vagy alkoholfogyasztás, nyugtatószedés szintén lehetséges stresszoldó módszerként jelenhet meg (Chen \& Cunradi, 2008; Pikó, 1999). Tanárok körében is igazolták, hogy a kiégés összefügg a coping stratégiák hatékonyságával: míg a hatékony módszerek (pl. kreatív hobbik) segítenek megelőzni, illetve kezelni a problémát, addig a kockázatos módszerek (pl. dohányzás és túlzott alkoholfogyasztás) növelik az esélyét (Seidman \& Zager, 1991). Mindenesetre bíztató, hogy Hongkongban sikerrel alkalmaztak egy olyan iskolai programot, amely hatékonyan csökkentette a kiégés tüneteit, egyben növelte az élettel való elégedettséget a tanárok körében (Chan, 2011).

Magyarországon a kiégés témájában egyre több kutatás valósult meg az elmúlt másfél évtizedben. Hazánkban elsősorban egészségügyi dolgozókat, főként ápolókat, nővéreket vizsgáltak, jóval kevesebb kutatás foglalkozott a pedagógusokkal. A kutatások egy része igazolta a kiégés, valamint a pszichés és testi megbetegedések kapcsolatát (Ádám, Győrffy, \& Csoboth, 2006; Irinyi \& Németh, 2012; Pikó, 2006). A kiégéssel kapcsolatban többen kutatták a szerepkonfliktust, mint rizikótényezőt (Győrffy \& Ádám, 2004; Ádám, Győrffy, \& Csoboth, 2006; Pikó, 2006), a stresszortényezóket (Petróczi, Fazekas, Tombácz, \& Zimányi, 1999, 2001; Piczil \& Pikó, 2012), valamint a megküzdési stratégiák (Kovács, Kovács, \& Hegedús, 2012; Torma, 2013) és a társas támogatás szerepét (Hegedûs, Riskó, \& Mészáros, 2004; Kovács és mtsai, 2012; Piczil \& Pikó, 2012). Vizsgálták továbbá a munkavégzés helyszínét (Pálfi, 2003), valamint a pályán eltöltött idő jelentőségét (Irinyi \& Németh, 2012; Kissné, 2009). 
Kifejezetten a pedagógusokra kiterjedő hazai vizsgálatok száma hazánkban csekély. Petróczi és munkatársai (1999) a pedagógusok és szociális területen dolgozók közérzetét, valamint a kiégés létrejöttében szerepet játszó egyéb tényezők jelenlétét vizsgálták, amelyben a legjelentősebb stresszortényezőkre hívták fel a figyelmet. A stresszortényezők hatására megjelenó tünetek közül a legmagasabb arányban az elégedetlenségérzés (58\%) jelentkezett, ezt követte a jövő miatti aggódás, a problémák jövőbeli megoldásának bizonytalansága, a koncentrációs problémák, az állandó fáradtságérzés, a kilátástalanság, a tehetetlenségérzés, a rosszabb egészségérzet, illetve közérzet. Salavecz és munkatársai (2006) kutatásának középpontjában a pedagógusok lelki egészsége és a munkahelyi stressz közti kapcsolat, valamint az énhatékonyság és a túlvállalás lelki egészségre gyakorolt hatásainak vizsgálata állt. Megállapították, hogy a különböző mentális egészségi változókra eltéró módon és mértékben hatnak a munkahelyi stressz káros hatásait is befolyásoló egyéni jellemzők. A pedagógusok lelki egészsége egyik fontos meghatározó tényezőjének az erőfeszítés-jutalom egyensúlytalanságát találták. A kiégés leginkább a munkahelyi stressztől függött. Kissné $(2009,2010)$ a nyugat-magyarországi pedagógusokat vizsgálta, és fóként a 21 évnél régebb óta dolgozó pedagógusok körében találta meghatározónak a kiégés gyakoriságát. Kutatási eredményei alapján elmondható, hogy a sport védelem lehet a kiégés ellen, fóként a nők esetében. Emellett a munkastílusnak is jelentősége van a kiégésre való veszélyeztetettség mértékében. Torma (2013) vizsgálatában azt találta, hogy a kiégés hátterében a legfontosabb protektív tényezőnek a megküzdés bizonyult, amelynek hatását a flow csak tovább erősítette.

Összességében megfogalmazhatjuk, hogy kifejezetten a pedagógusok körében előforduló kiégés, valamint lelki egészségük és egészségmagatartásuk kapcsolatára vonatkozóan kevés adat áll a rendelkezésünkre, így kutatásunk fontos hiányt pótolhat. Kutatásunk fókuszába ezért pedagógusok körében végzett online adatgyújtés segítségével a pedagógusok lelki egészségét helyeztük. Az elemzésben az élettel való elégedettség szerepelt mint függő változó, független változóként pedig bevontuk az egészségmagatartás, a kiégés tüneteit és az egészséggel kapcsolatos egyéb változókat. Kontrollváltozóként a szociodemográfiai változókat (életkor, nem, társadalmi helyzet megítélése) szintén bevettünk az elemzésekbe.

\section{Módszer}

\subsection{Vizsgálati személyek és eljárás}

Az adatokat 2016. december és 2017. január között, egyhónapos időszakban gyújtöttük. A pedagógusok megkérdezését az Oktatási Hivatal köznevelés 
információs rendszerének (KIR) központi oldaláról letölthető közérdekú köznevelési adatok (Múködő köznevelési intézmények feladatellátási helyei ${ }^{1}$ adatbázisából biztosítottuk. A feladatellátási helyek központi adatfájljából (összesen $=14000$ ) minden 10. intézményt véletlenszerúen választottunk ki, szisztematikus mintavételt alkalmaztunk. A leendő válaszadókat e-mailben kerestük meg, amelyben tájékoztatást nyújtottunk a kutatás céljáról, illetve felkértük őket a kutatásban való részvételre. A Szegedi Tudományegyetem Neveléstudományi Doktori Iskola Etikai Bizottságának etikai jóváhagyása után az adatokat online kérdőíves felméréssel gyújtöttük, e-mailben csatolt link segítségével. A válaszadók száma 2068 fó (átlagéletkor: 48,1 év; SD = 8,9 év; terjedelem: $23-74$ év; a minta 83,5\%-a [ $n=1726]$ nó. Legtöbben az 50-59 éves (42,2\%) és a 40-49 éves (33,2\%) korcsoportból töltötték ki a kérdőívet, 17,1\%-uk 40 év alatti, míg 7,6\%-uk 60 év feletti volt. A kutatásban való részvétel anonim és önkéntes volt, önbevallásos adatok alapján történt. A résztvevők a kérdőív kitöltésével és visszaküldésével beleegyezésüket fejezték ki a kutatásban való részvételre.

\subsection{Mérőeszközök}

A kérdőív a szociodemográfiai (kor, nem, társadalmi helyzet önbesorolása: alsó, alsó-közép, közép, felső-közép és felső osztály) adatokon túl tartalmazta a pedagógusok lelki egészségével, egészségmagatartásával és egyéb, munkahelyi környezetével kapcsolatos változókat.

A kiégés mérésére a Maslach-féle Kiégés Leltár (Maslach Burnout Inventory, a továbbiakban MBI), pedagógus változatát használtuk (Maslach \& Jackson, 1986; Kovács és mtsai, 2012), amelynek célja a munkahelyi stressz felmérése (pl. „A munkám érzelmileg kimerít”; „Úgy érzem, van néhány tanuló, akit úgy kezelek, mintha nem lenne külön egyéniségük”; „Könnyen megértem, hogy a tanulók mikor mit éreznek"). A 22 itemú MBI három alskálából áll: az érzelmi kimerültség, az elszemélytelenedés (deperszonalizáció), és a személyes teljesítmény csökkenése alskálákból. A válaszadás hétfokozatú, Likert-típusú skálán történik a soha nem éltem át (0) és minden nap átélem (6) végpontok között. A Cronbach-a értékei az aktuális mintán a következő́k voltak: 0,89 (MBI), 0,89 (érzelmi kimerülés), 0,73 (elszemélytelenedés) 0,77 (személyes hatékonyság csökkenése).

Az egészségi állapot és az egészségmagatartás feltárására az Európai Lakossági Egészségfelmérés (a továbbiakban ELEF) 2014-es kutatási kérdőívének egyes kérdéseit használtuk fel, ${ }^{2}$ amelyet egy esetben saját kérdéssel egészí-

${ }^{1}$ Letöltve: 2016. 11. 14-én: https:// dari.oktatas.hu/index.php?id=kozerdeku

2 Letöltve: 2016. 11. 14-én: https://www.ksh.hu/docs/hun/xftp/stattukor/elef14.pdf 
tettünk ki. Az egészség önértékelésre a „Milyen az Ön egészsége általában?" kérdést használtuk, a válaszok értékelése egy ötfokozatú, Likerttípusú skálán történt a nagyon rossz (1) és a nagyon jó (5) végpontok között. Az elemzésekhez a változót dichotomizáltuk ( 1 = nagyon rossz/rossz/ kielégító, 2 = jó/nagyon jó).

A dohányzás mérésére ebben a tanulmányban az egyszerú dichotóm változót alkalmaztuk (dohányzik/nem dohányzik jelenleg).

Az alkoholfogyasztást két kérdéssel vizsgáltuk. Az első kérdés: „Az elmúlt 12 hónapban milyen gyakran fogyasztott Ön alkoholtartalmú italt (mint például sör, bor, pezsgő, pálinka, vodka, rum, whisky, koktél, likőr, alkoholos üdítő, házilag elóállított alkohol...)?". A válaszadás kilencfokozatú, Likert-típusú skálán történt a soha, vagy egész életében csak néhány kortyot ivott (1) és a minden nap vagy majdnem minden nap (9) végpontok között. Az elemzések során itt is dichotóm változót alkalmaztunk $(1=$ nem fogyasztott alkoholt az elmúlt 12 hónapban/vagy csak alkalmanként és 2 = legalább havonta többször fogyasztott alkoholt, mennyiségtól függetlenül). A második kérdés: „Az elmúlt 12 hónapban milyen gyakran fogyasztott Ön egy alkalommal 6 vagy annál több alkoholtartalmú italt (egy ital alatt egy korsó sört vagy két dl bort vagy fél dl röviditalt értünk)? Például egy buli alatt, étkezés közben, baráti összejövetel, esti kikapcsolódás alkalmával, vagy akár egyedül, otthon..." A válaszadás az előző kérdéshez hasonlóan kilencfokozatú skálán történt. Az elemzések során itt is dichotóm változót alkalmaztunk ( 1 = egyszer sem az elmúlt 12 hónapban és 2 = legalább egyszer).

Végül megkérdeztük a résztvevóket, hogy egy átlagos héten hány percet töltenek szabadidejükben sportos tevékenységekkel (perc/hét).

A pszichoszomatikus tünetek megismeréséhez a Pszichoszomatikus tüneti indexet alkalmaztuk (Pikó, 2006). A hét kérdésből álló skála a következő tünetek gyakoriságára terjed ki: fejfájás, hát- és derékfájás, alvási problémák, fáradtságérzés, gyomorégés, idegességből eredő hasmenés és palpitáció. A felsorolt tünetek elófordulásáról az előző 12 hónapra vonatkozóan gyújtöttünk adatokat. A válaszadás egy négyfokozatú Likert-típusú skálán történt, az alábbi válaszlehetőségekkel: soha (1), ritkán (2), időnként (3), és gyakran (4). A skála belső megbízhatóságát mérő Cronbach-a értéke 0,78 volt.

Az élettel való elégedettséget a szubjektív jóllét mérésére használt, Diener-féle Élettel Való Elégedettség Skálával (Satisfaction with Life Scale; SWLS) mértük (Diener, Emmons, Larsen, \& Griffin, 1985; Martos, Sallay, Désfalvy, Szabó, \& Ittzés, 2014). A skála öt itemből áll, pl. „Az életem a legtöbb szempontból közel van az általam elképzelthez.". A válaszadás egy 
hétfokozatú Likert-típusú skálán történt az egyáltalán nem értek egyet az állítással (1) és a teljesen egyetértek az állítással (7) végpontok között. A magasabb pontszám nagyobb élettel való elégedettséget jelez. A skála Cronbach-a értéke a jelen mintán 0,89 volt.

\subsection{Alkalmazott statisztikai elemzések}

A statisztikai elemzéshez SPSS for windows 15.0 programot használtunk. Az elemzés leíró statisztikával kezdődött, amelynek során a skálák átlag- és szórásértékei, valamint a százalékos gyakoriságok kerültek kiszámításra. Ezt követően a változók közötti kapcsolatok elemzéséhez korrelációs együtthatókat számítottunk. Végül az élettel való elégedettség magyarázó változóit többváltozós lineáris regresszió elemzéssel teszteltük, enter módszerrel. A regressziós modell megbízhatóságának ellenőrzéséhez tolerancia és VIF mutatókat vontunk be.

\section{Eredmények}

Az 1. táblázat tartalmazza a vizsgálatban szereplő változók leíró statisztikáját. A kiégés összpontszámának átlagértéke 51,5-nek $(\mathrm{SD}=17,7)$ bizonyult. A megkérdezettek közül kevesebben sorolták be magukat az alsó és alsóközép osztályba (32,8\%), mint a közép és felső osztályokba (67,2\%). Saját egészségüket jónak és nagyon jónak ítélte meg a megkérdezettek többsége (61,2\%). A káros szenvedélyek előfordulási gyakorisága a következő volt: a jelenleg dohányzók aránya: 16,8\%, az elmúlt 12 hónapban legalább havonta többszöri alkoholfogyasztás: 51,2\%, nagyivás: 33,3\%. A megkérdezett pedagógusok átlagban hetente 119,3 (SD = 170,1) percet (közel két órát) sportolnak. 
1. táblázat. A pedagógusokat jellemző változók leíró statisztikája

\begin{tabular}{|c|c|c|}
\hline Változók & $\begin{array}{c}\text { Gyakoriság } \\
n(\%)\end{array}$ & $\begin{array}{c}\text { Átlag (SD) } \\
\text { [terjedelem] }\end{array}$ \\
\hline Kor (év) & & $\begin{array}{c}48,1(8,9) \\
{[23-74]}\end{array}$ \\
\hline $\begin{array}{l}\text { Nem } \\
\text { Férfi } \\
\text { Nó }\end{array}$ & $\begin{array}{c}342(16,5) \\
1726(83,5)\end{array}$ & \\
\hline $\begin{array}{l}\text { Társadalmi helyzet megítélése } \\
\text { Alsó/alsó-közép osztály } \\
\text { Közép/ felső-közép/felső osztály }\end{array}$ & $\begin{array}{c}619(32,8) \\
1270(67,2)\end{array}$ & \\
\hline Kiégés (MBI) összpontszám & & $\begin{array}{c}51,5(17,7) \\
{[8-118]}\end{array}$ \\
\hline Érzelmi kimerültség (MBI) & & $\begin{array}{l}23,7(10,5) \\
{[0-54]}\end{array}$ \\
\hline Elszemélytelenedés (MBI) & & $\begin{array}{c}7,2(5,3) \\
{[0-30]}\end{array}$ \\
\hline $\begin{array}{l}\text { Személyes teljesítmény csökkenése } \\
\text { (MBI) }\end{array}$ & & $\begin{array}{c}20,7(6,3) \\
{[8-54]}\end{array}$ \\
\hline Pszichoszomatikus tünetek & & $\begin{array}{l}16,0(4,4) \\
{[7-28]}\end{array}$ \\
\hline $\begin{array}{l}\text { Egészség önértékelése } \\
\text { Nagyon rossz/rossz/kielégítő } \\
\text { Jó/nagyon jó }\end{array}$ & $\begin{array}{l}803(38,8) \\
1265(61,2)\end{array}$ & \\
\hline $\begin{array}{l}\text { Dohányzás (jelenleg) } \\
\text { Nem } \\
\text { Igen }\end{array}$ & $\begin{array}{c}1720(83,2) \\
348(16,8)\end{array}$ & \\
\hline $\begin{array}{l}\text { Alkoholfogyasztás (elmúlt } 12 \text { hó) } \\
\text { Nem/csak alkalmanként } \\
\text { Legalább havonta többször }\end{array}$ & $\begin{array}{l}1010(48,8) \\
1058(51,2)\end{array}$ & \\
\hline $\begin{array}{l}\text { Nagyivás (elmúlt } 12 \text { hó) } \\
\text { Nem } \\
\text { Igen }\end{array}$ & $\begin{array}{c}1370(66,7) \\
683(33,3)\end{array}$ & \\
\hline Sportolás (perc/hét) & & $\begin{array}{c}119,3(170,1) \\
{[0-3600]}\end{array}$ \\
\hline Élettel való elégedettség (SWLS) & & $\begin{array}{c}24,6(5,9) \\
{[5-35]}\end{array}$ \\
\hline
\end{tabular}

Megjegyzés: MBI: Maslach-féle Kiégés Leltár, SWLS: Élettel Való Elégedettség Skála. 
A 2. táblázat a változók közötti kapcsolatokat mutatja be korrelációs mátrix formájában. Eredményeink szerint az életkor előrehaladtával csökken a kiégés alskálái közül az elszemélytelenedés és a személyes teljesítménycsökkenés, bár az összefüggés csekély mértékủ. A korral romlik az egészségi állapot szubjektív megítélése is, és az idősebb pedagógusok nemcsak a társadalmi helyzetüket ítélik meg rosszabbnak, hanem saját életükkel is elégedetlenebbek. A kor mellett a nemmel való összefüggések is bár szignifikáns, de csak csekély erősségú kapcsolatot jeleznek: a női pedagógusok jobbnak ítélik saját társadalmi helyzetüket, és elégedettebbek saját életükkel is, mint a férfi pedagógusok. Míg az érzelmi kimerültség a nókre valamelyest jellemzőbb, az elszemélytelenedést és a személyes teljesítménycsökkenést a férfiak jelezték inkább. Az alkoholfogyasztás (a nagyivás is) a férfiakra jellemzőbb a nőkhöz képest. Az alkoholfogyasztás továbbá összefügg a kiégés elszemélytelenedés alskálájával. A korrelációs együtthatók itt is kismértékú kapcsolatot jeleznek a szignifikancia ellenére. A kiégés és a pszichikaiegészség-mutatók között figyelhetóek meg a legnagyobb mértékú kapcsolatok. A kiégés valamennyi alskálája pozitívan korrelál a pszichoszomatikus tünetképzéssel (a legerősebb kapcsolat az érzelmi kimerültséggel mutatkozik: $r=0,58 ; p<0,001$ ), és negatívan az egészség önértékelésével, valamint az élettel való elégedettséggel. Összefüggés igazolható ezenkívül a dohányzás és az alkoholfogyasztás között, valamint megállapítható, hogy a dohányzás nemcsak az egészségi állapot rosszabb szubjektív megítélésével jár együtt, hanem az élettel való elégedettség alacsonyabb mértékével is. A sportolás a kiégés-faktorok közül enyhe negatív korrelációt mutat az érzelmi kimerültséggel és a személyes teljesítmény csökkenéssel, csakúgy, mint a pszichoszomatikus tünetekkel. A sport kismértékben együtt jár továbbá az egészség jobb értékelésével és az élettel való nagyobb elégedettséggel, valamint az alkoholfogyasztással is. A nők körében a sporttal töltött idő valamivel kevesebb, mint a férfiaknál; az életkorral viszont nem csökken a sportolás mértéke. 


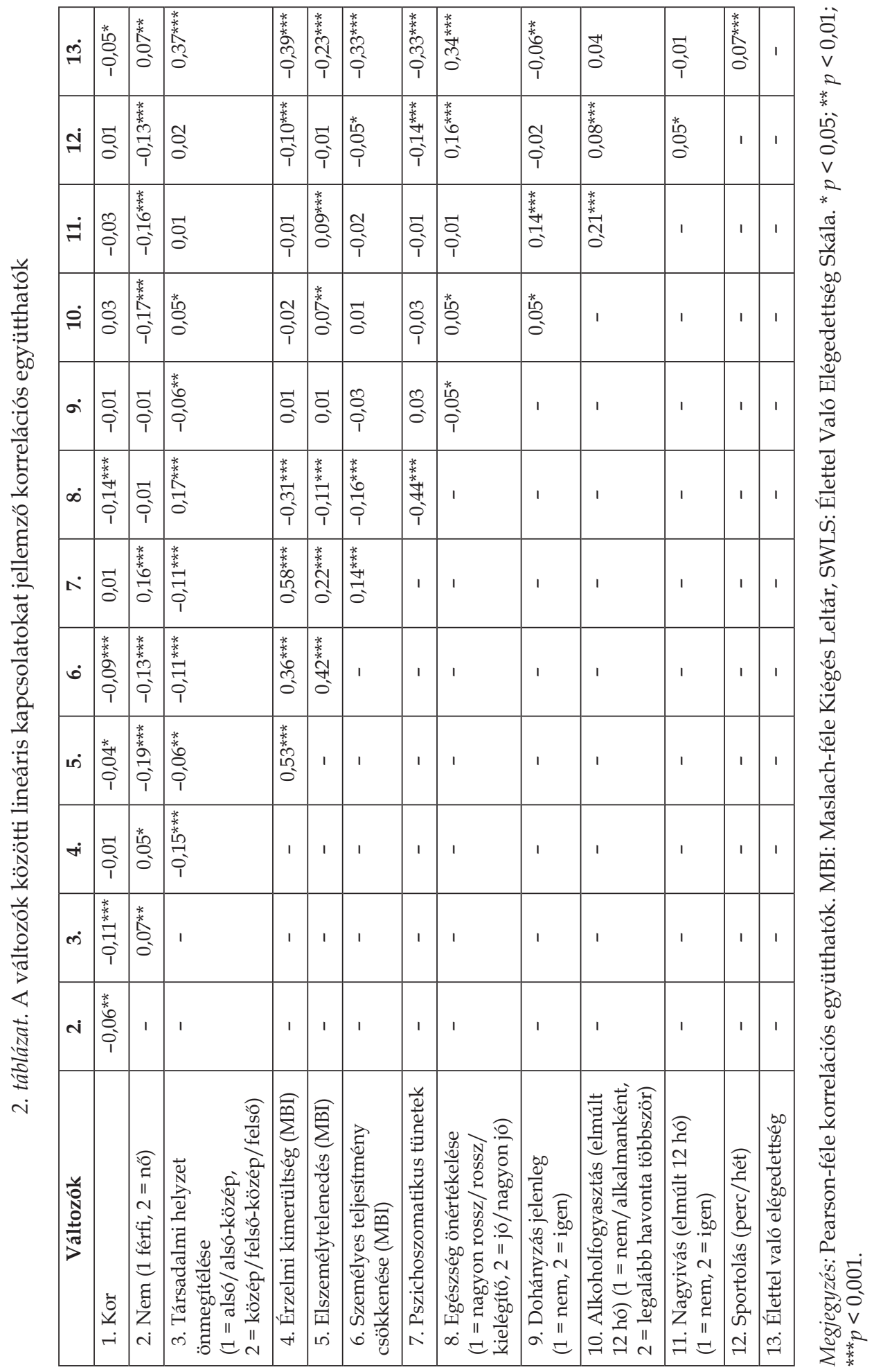


A 3. táblázat az élettel való elégedettséget, mint a lelki egészség mutatóját magyarázó/előrejelző független egészség- és szociodemográfiai (kontroll) változók többváltozós lineáris regresszió elemzését tartalmazza. Látható, hogy a kiégés két faktora jelzi előre leginkább az élettel való elégedettséget, méghozzá legerősebben a személyes teljesítménycsökkenés $(\beta=-0,21 ; p<$ $0,001)$, amit az érzelmi kimerültség követ $(\beta=-0,18 ; p<0,001)$. A regressziós modellben ezt követi a pszichoszomatikus tünetek gyakorisága $(\beta=$ $-0,14 ; p<0,001)$ és a saját egészség megítélése $(\beta=0,12 ; p<0,001)$. Míg azonban ezeknek a pszichoszomatikus tüneteknek a jelenléte alacsonyabb, az egészségi állapot önmegítélése az élettel való elégedettség skála magasabb pontszámával függ össze. Az egészségmagatartási változók közül a dohányzás negatív $(\beta=-0,04 ; p=0,036)$, míg az alkoholfogyasztás $(\beta=0,07$; $p=0,001)$ pozitív irányú kapcsolatot mutat az élettel való elégedettséggel. Csakúgy, mint a társadalmi helyzet magasabb önbesorolása $(\beta=0,21$; $p<0,001)$. A nagyivás és a sportolás a modellben nem mutat szignifikáns kapcsolatot az élettel való elégedettséggel.

Eredményeinket összefoglalva elmondható, hogy azok elégedettebbek az életükkel, akik kevésbé szenvednek a kiégés tüneteitől és egyéb pszichoszomatikus tünetektől, nem dohányoznak, ellenben jónak ítélik saját egészségüket, legalább havonta többször fogyasztanak alkoholt (de nem a nagyivás szintjéig), és magukat magasabb társadalmi osztályba sorolják. A többi kontrollváltozót tekintve azt állapíthatjuk meg, hogy a női pedagógusok szignifikánsan elégedettebbek az életükkel, mint a férfiak ( $\beta=0,06$; $p=0,002)$, a kor azonban nem befolyásoló tényezó. A modell az élettel való elégedettség varianciájának számottevő hányadát (28\%) megmagyarázza. A tolerancia és a VIF értékek mutatják, hogy a magyarázó változók közötti multikollinearitás nem számottevő, azaz alkalmasak regressziós modell kialakítására.

\section{Megbeszélés}

A kiégés olyan, a segítő hivatásúakat sújtó jelenség, amely kihat a munkavégzők teljesítményére, motivációjára, munkával való elégedettségére, életminőségére és egészségi állapotára (Grossi és mtsai, 2003; Kovács, 2006; Leiter és mtsai, 2014; Montgomery és mtsai, 2005). A pedagógusok testi és lelki egészségét a munkahelyi stresszel összefüggésben számos nemzetközi kutatásban vizsgálták (Chan, 2011; Chen \& Cunradi, 2008; Hakanen és mtsai, 2006; Montgomery és mtsai, 2005; Seidman \& Zager, 1991). Hazánkban szintén folytak kutatások a pedagógusok kiégésével kapcsolatban (pl. Kissné, 2009; Petróczi és mtsai, 1999; 2001; Salavecz és mtsai, 2006; Torma, 2013), azonban jóval kevesebb, mint azt a téma fontossága indokolná. Kutatásunk fókuszába ezért a hazai pedagógusok életminőségét, lelki egészségét és egészségmagatartását állítottuk. A vizsgálatban több mint 2000 pedagógus vett részt, 83,5\%-uk nő, ami jól jelzi a pálya elnőiesedését. 
3. táblázat. A pedagógusok élettel való elégedettségét magyarázó változók (többváltozós lineáris regresszió elemzés)

\begin{tabular}{|l|r|r|r|r|c|}
\hline \multicolumn{1}{|c|}{ Változók } & $\boldsymbol{\beta}$ & $\boldsymbol{1}$ & $\boldsymbol{t}$ & Tolerancia & VIF \\
\hline Érzelmi kimerültség (MBI) & $-0,18$ & $<0,001$ & $-6,135$ & 0,475 & 2,104 \\
\hline Elszemélytelenedés (MBI) & 0,01 & 0,566 & 0,574 & 0,617 & 1,620 \\
\hline $\begin{array}{l}\text { Személyes teljesítmény csökkenése } \\
\text { (MBI) }\end{array}$ & $-0,21$ & $<0,001$ & $-9,235$ & 0,772 & 1,295 \\
\hline Pszichoszomatikus tünetek & $-0,14$ & $<0,001$ & $-5,360$ & 0,563 & 1,775 \\
\hline $\begin{array}{l}\text { Egészség önértékelése (1 = nagyon } \\
\text { rossz/rossz/kielégítő, 2 = jó/ } \\
\text { nagyon jó) }\end{array}$ & 0,12 & $<0,001$ & 5,104 & 0,737 & 1,357 \\
\hline Dohányzás (1 = nem, 2 = igen) & $-0,04$ & 0,036 & $-2,102$ & 0,966 & 1,035 \\
\hline $\begin{array}{l}\text { Alkoholfogyasztás (1 = nem/ } \\
\text { alkalmanként, 2 = legalább havonta } \\
\text { többször) }\end{array}$ & 0,07 & 0,001 & 3,192 & 0,924 & 1,082 \\
\hline Nagyivás (1 = nem, 2 = igen) & $-0,01$ & 0,819 & $-0,228$ & 0,909 & 1,100 \\
\hline Sportolás mennyisége (perc/hét) & $-0,01$ & 0,945 & $-0,069$ & 0,941 & 1,063 \\
\hline Kor & $-0,03$ & 0,083 & $-1,735$ & 0,946 & 1,058 \\
\hline Nem (1 = férfi, 2 = nó) & 0,06 & 0,002 & 3,048 & 0,857 & 1,167 \\
\hline $\begin{array}{l}\text { Társadalmi helyzet önbesorolása } \\
(1=\text { alsó/alsó-közép, } \\
\text { 2 = közép/felső-közép/felső) }\end{array}$ & 0,21 & $<0,001$ & 10,414 & 0,941 & 1,062 \\
\hline
\end{tabular}

Megjegyzés: MBI: Maslach-féle Kiégés Leltár. $\beta$ : standardizált regressziós együtthatók; Tolerancia és VIF (Variance Inflation Factor): a multikollinearitás mérőszámai. Korrigált $\mathrm{R}^{2}=0,28$.

A kiégés egyes faktorainak átlagait a nemzetközi adatok tükrében elemezve a következőket állapíthatjuk meg. Az érzelmi kimerültség átlagértéke $(23,7)$ magasabb, mint a namíbiai (19,7: Louw, George, \& Esterhuyse, 2011), a spanyol (17,9: Aluja, Blanch, \& Garcia, 2005), a német (19,5: Schwarzer, Schmitz, \& Tang, 2000), a kínai (22,4: Schwarzer és mtsai, 2000), és hasonló, mint az ausztrál minta eredménye (23,3: Dorman, 2003). Az elszemélytelenedés alskála átlagértéke $(7,2)$ pontosan megegyezik az ausztrállal, azonban jóval magasabb a többi nemzetközi értéknél. A személyes teljesítmény (átlag = $30,7)$ esetében már kissé más a helyzet: ez az érték az ausztrál és a kínai értéknél magasabb, de alacsonyabb a spanyol, a namíbiai és a német értékeknél. Az összesített skála átlagértéke $(51,5)$ pedig nagyobb, mint a 2006-ban 
végzett pedagógusvizsgálat eredménye (42,5: Salavecz és mtsai, 2006), ez azonban mindössze 87 pedagógus részvételével történt. Ezek az összehasonlítások jól jelzik, hogy a kiégés, mint probléma jelen van a hazai pedagógustársadalomban. Ahhoz azonban, hogy tényszerú következtetéseket tudjunk levonni az összehasonlító adatok hátteréről, az eltérő iskolarendszer behatóbb tanulmányozására, valamint további, pl. kultúraközi kutatásokra lenne szükség.

A kétváltozós vizsgálatok rámutattak arra, hogy a kiégés dimenziói negatívan függnek össze az élettel való elégedettséggel, a saját egészség megítélésével és pozitívan a pszichoszomatikus tünetek gyakoriságával. Érdemes külön kiemelni az érzelmi kimerültség és a pszichoszomatikus tünetek közötti kifejezetten erós kapcsolatot. Ezek az eredmények egybecsengnek korábbi kutatási eredményekkel (Cazan \& Năstasă, 2015; Leiter és mtsai, 2014; Pikó, 2003). Az alskálák közül az elszemélytelenedés kapcsolatba hozható az alkoholfogyasztással és a nagyivással. S bár a dohányzás a kiégéssel közvetlenül nem hozható összefüggésbe, az élettel való elégedettség alacsonyabb mértékével jár együtt. A sportolás viszont a kiégés faktoraival negatív, az élettel való elégedettséggel és az egészség megítélésével viszont pozitív kapcsolatba hozható, ami Kissné (2009) adatait erősíti. Érdemes még kiemelni, hogy míg az érzelmi kimerültség a nők körében magasabb, a másik két faktor a férfiak körében. Egy kiégéssel foglalkozó összefoglaló tanulmányban hasonló eredményre jutottak (Purvanova \& Muros, 2010), aminek az oka egyrészről a nők nagyobb magánéleti terheltsége és gyakoribb szerepkonfliktusai, másrészról viszont a férfiak nagyobb teljesítményorientáltsága, míg az elszemélytelenedés egyfajta védekezés is lehet részükról. Az életkor előrehaladtával csökken az elszemélytelenedés, és kisebb mértékú lesz a teljesítmény csökkenése is. Egy korábbi nemzetközi tanulmány (Antoniou \& Polychroni, 2006) szintén a fiatalabb tanárok nagyobb kiégés veszélyeztetettségéról számolt be, ami a karrierkezdési nehézségekből is eredeztethető. A társadalmi helyzet jobb megítélésével a kiégésnek ez a két dimenziója szintén fordított irányú összefüggést mutat.

A többváltozós elemzés eredményei révén kiderült, hogy a vizsgált változók közül leginkább a kiégés faktorai a legerôsebb prediktorai az élettel való elégedettségnek, közülük is a személyes teljesítménycsökkenés és az érzelmi kimerültség játszik szerepet az élettel való elégedettség mértékében. Az érzelmi kimerültség szerepe összecseng korábbi vizsgálatok eredményeivel, ami nemcsak az életminőségre, hanem a munkával való elégedettségre és pályaelhagyásra is hatással van (Skaalvik \& Skaalvik, 2011). A személyes teljesítmény csökkenésének jelentősége arra utal, hogy a teljesítményorientáltság igen fontos a pedagógusok számára. Mérsékelt erősségú a szerepe az élettel való elégedettségben a pszichoszomatikus tünetek gyakoriságának és az egészség önértékelésének, míg csekély mértékben a dohányzás- 
nak, negatív előjellel. Korábbi kutatások is hasonló összefüggésekről számoltak be (vö. Leiter és mtsai, 2014). Míg a mérsékelt alkoholfogyasztás az élettel való elégedettséget csekély mértékben emeli, a nagyivás már nincs rá hatással. A szociodemográfiai mutatók körül a legerősebb szerepet a társadalmi helyzet önbesorolása játszotta. A korral nem változik jelentósen, viszont azok körében, akik magasabb társadalmi helyzetúnek sorolták be magukat, az élettel való elégedettség is nagyobb mértékú. A nem szerepe ebben kevésbé meghatározó, de a nők valamennyire elégedettebbek saját életükkel. A sport protektív szerepét nem sikerült maradéktalanul igazolni, további vizsgálatok szükségesek az összefüggés pontosabb megismerésére.

A kutatás korlátait tekintve meg kell említeni, hogy keresztmetszeti jellegú vizsgálat lévén ok-okozati kapcsolatok igazolására ezek az adatok nem alkalmasak. A társadalmi helyzet és a pszichológiai változók közötti kapcsolatok pl. fordított irányú vagy akár cirkuláris összefüggéseket is jelezhetnek. A kétváltozós kapcsolatok értelmezéséhez meg kell jegyezni, hogy a korrelációk mértéke sok esetben - bár a nagy elemszám miatt szignifikánsnak bizonyultak - meglehetősen alacsony értékúek.

\section{Következtetés}

Összefoglalásként tehát elmondhatjuk, hogy a kiégés valós probléma a hazai pedagógusok körében, nemzetközi összehasonlításban is magas értéket képviselnek a pontszámok átlagértékei. A kiégés szempontjából különösen veszélyeztetettek a férfiak és a fiatalabb tanárok, akik valószínúleg kevésbé rendelkeznek kelló rutinnal, ami segítene a munkahelyi stresszel való megbirkózásban. Korábbi kutatások szerint a megküzdésnek lehet kiemelt szerepe, ami a kiégés megelőzésében különösen fontos lehet (Antoniou \& Polychroni, 2006; Kovács és mtsai, 2012; Torma, 2013). A három faktor közül az elszemélytelenedés és a személyes teljesítmény csökkenése egyaránt a férfi pedagógusokra jellemzőbb. Ez az a faktor egyébként, ami a legmeghatározóbb az élettel való elégedettség mértékében, a személyes teljesítménycsökkenés mellett. A kiégés szorosan összefügg a pedagógusok lelki egészségével, így a pszichoszomatikus tüneteikkel, az egészségi állapotuk önmegítélésével. Míg a nagyivás nem jellemző a mintára, a mérsékelt alkoholfogyasztás pozitív összefüggést mutat az elszemélytelenedéssel. Mivel vizsgálatunk keresztmetszeti jellegú, ok-okozati kapcsolatot nem tudunk igazolni, de feltételezhető, hogy az alkoholfogyasztásnak egyfajta coping funkciója is lehet. Ezt alátámasztani látszik az is, hogy az élettel való elégedettséggel összefüggésben is pozitív a kapcsolat, szemben a dohányzással, ami negatív. 
A megelőzésben egyéni és szervezeti szinten egyaránt fontos teendőink vannak. Egyéni szinten a pszichológiai immunkompetencia (Oláh, 2005) és a védőfaktorok erősítése (Szicsek, 2004), hatékony coping stratégiák elsajátítása jelenthet megoldást, akár a tanárképzés részeként. Pszichológiai tanácsadás, szupervízió biztosítása szintén a megelőzést szolgálhatja. Szervezeti szinten pedig a munkahelyi környezet alacsonyabb stressz-szintúvé alakítása, a szerepkonfliktusok és egyéb terhek csökkentése mellett a támogató kapcsolati háló jöhet számításba (Skaalvik \& Skaalvik, 2011). Nemzetközi szinten számos különböző intervenciós módszert dolgoztak ki a pedagógus kiégés kezelésére, amelyek a hatékony coping és kommunikációs stratégiák mellett relaxációs módszereket és egyéb pszichoterápiás, a hatékony stresszoldást segítő technikákat alkalmaznak; ezek egy része személy-, más része szervezetközpontú, és léteznek online intervenciós módszerek is (Horváth, 2014). A bevezetésben már említett hongkongi programban egy nyolchetes, pozitív pszichológiai szemléletú intervenciót alkalmaztak, amelynek során a résztvevőknek naplószerúen pozitív életeseményekre és a hála kifejezésére kellett fókuszálniuk. Az intervenció utáni mérés megállapította, hogy nemcsak az élettel való elégedettség mértéke nőtt meg, hanem az érzelmi kimerültség is csökkent (Chan, 2011).

\section{Irodalom}

Ádám, Sz., Győrffy, Zs., \& Csoboth, Cs. (2006). Kiégés (burnout) szindróma az orvosi hivatásban. Hippocrates, 8(2), 113-117.

Aluja, A., Blanch, A., \& Garcia, L.F. (2005). Dimensionality of the Maslach Burnout Inventory in school teachers: A study of several proposals. European Journal of Psychological Assessment, 21(1), 67-76.

Antoniou, A.-S.,\& Polychroni, F. (2006). Gender and age differences in occupational stress and professional burnout between primary and highschool teachers in Greece. Journal of Managerial Psychology, 21(7), 682-690.

Bordás, A. (2010). A kiégés-szindróma a külföldi és a hazai szakirodalomban. Educatio, 19(4), 666-672.

Cazan, A.-M., \& Năstasă, L.E. (2015). Emotional intelligence, satisfaction with life and burnout among university students. Procedia - Social and Behavioral Sciences, 180, 15741578.

Chan, D.W. (2011). Burnout and life satisfaction: Does gratitude intervention make a difference among Chinese school teachers in Hong Kong? Educational Psychology, 31(7), 809-823.

Chen, M.-J., \& Cunradi, C. (2008). Job stress, burnout and substance use among urban transit operators: The potential mediating role of coping behaviour. Work $\mathcal{E}$ Stress, 22(4), 327340.

Diener, E., Emmons, R.A., Larsen, R.J., \& Griffin, S. (1985). The Satisfaction With Life Scale. Journal of Personality Assessment, 49(1), 71-75. 
Dorman, J. (2003). Testing a model for teacher burnout. Australian Journal of Educational E Developmental Psychology, 3, 35-47.

ELEF (2014). Európai Lakossági Egészségfelmérés. Budapest: Központi Statisztikai Hivatal. Letöltve: 2016. 11. 14-én: http:/ / www.ksh.hu/elef

Fekete, S. (1991). Segítő foglalkozások kockázatai: Helfer-szindróma és Burnout jelenség. Psychiatria Hungarica, 6(1), 17-29.

Grossi, G., Perski, A., Eventgård, B., Blomkvist, V. \& Orth-Gomér, K. (2003). Physiological correlates of burnout among women. Journal of Psychosomatic Research, 55(4), 30-316.

Győrffy, Zs., \& Ádám, Sz. (2004). Az egészségi állapot, a munkastressz és a kiégés alakulása az orvosi hivatásban. Szociológiai Szemle, 14(3), 107-127.

Hakanen, J.J., Bakker, A.B., \& Schaufeli, W.B. (2006). Burnout and work engagement among teachers. Journal of School Psychology, 43(6), 49-513.

Hegedûs, K., Riskó, Á., \& Mészáros, E. (2004). A súlyos betegekkel foglalkozó egészségügyi dolgozók testi és lelki állapota. Lege Artis Medicinæ, 14(11), 786-793.

Horváth, Sz. (2014). Pedagógus burnout prevenciójának lehetőségei. In J.T. Karlovitz (Szerk.), Mozgás, környezet, egészség (155-173). Komarno: International Research Institute s.r.o.

Irinyi, T., \& Németh, A. (2012). A szakdolgozói társadalmat járványszerúen megfertőző kór neve: kiégés. Nôvér, 25(5), 12-18.

Kiss-Geosits, B. (2010). Untersuchung de Faktoren, die hinsichtlich des Burn-outs von westungarischen Pädagogen von Bedeutung sind. European Journal of Mental Health, 5(2), 239-256.

Kissné Geosits, B. (2009). Sport, pályaválasztás és a lelki egészség a nevelés, oktatás területén dolgozó szakembereknél. Doktori értekezés. Budapest: Semmelweis Egyetem

Kovács, M. (2006). A kiégés jelensége a kutatási eredmények tükrében. Lege Artis Medicinæ,16(11), 981-987.

Kovács, M., Kovács, E., \& Hegedús, K. (2012). Az érzelmi munka és a kiégés összefüggései egészségügyi dolgozók különböző csoportjaiban. Mentálhigiénéés Pszichoszomatika, 13(2), 219-241.

Leiter, M.P., Bakker, A.B., \& Maslach, C. (2014). Burnout at work - A psychological perspective. London \& New York: Psychology Press, Taylor \& Francis Group.

Louw, D.A., George, E., \& Esterhuyse, K. (2011). Burnout amongst urban secondary school teachers in Namibia. SA Journal of Industrial Psychology, 37(1), 201-207.

Martos, T., Sallay, V., Désfalvy, J., Szabó, T., \& Ittzés, A. (2014): Az Élettel való Elégedettség Skála magyar változatának (SWLS-H) pszichometriai jellemzói. Mentálhigiéné és Pszichoszomatika, 15(3), 289-303.

Maslach, C., \& Jackson, S.E. (1982). Burnout in health professions. A social psychological analysis. In G.S. Sanders, \& J. Suls (Eds.), Social psychology of health and illness (227-247). Hillsdale NJ.: Erlbaum

Maslach, C., \& Jackson, S.E. (1986): Maslach Burnout Inventory. Palo Alto: Consulting Psychologists Press

Maslach, C., Schaufeli, W.B., \& Leiter, M.P. (2001). Job burnout. Annual Review Psychology, 52(1), 397-422.

Mihálka, M. (2015). A kiégésről - nemzetközi és hazai kutatási kitekintés. Acta Sana: „Mens sana in corpore sano" Az egészségügyi és a szociális ellátás elmélete és gyakorlata. 10(2), 7-18.

Montgomery, A., Mostert, K., \& Jackson, L. (2005). Burnout and health or primary school educators in the North West Province. South African Journal of Education, 24(4), 266-272.

Oláh, A. (2005). Érzelmek, megküzdés és optimális élmény. Belső világunk megismerésének módszerei. Budapest: Trefort Kiadó 
Pálfi, F.-né (2003). Szolgálat, önfeláldozás, hivatás? - A kiégés veszélyei ápolók körében. Nővér, 16(6), 3-9.

Petróczi, E., Fazekas, M., Tombácz, Zs., \& Zimányi, M. (1999). A kiégés jelensége pedagógusoknál. Magyar Pszichológiai Szemle, 54(3), 429-441.

Petróczi, E., Fazekas, M., Tombácz, Zs., \& Zimányi, M. (2001). A kiégés jelensége pedagógusoknál. Új Pedagógiai Szemle, 52(6), 127-139.

Piczil, M., \& Pikó, B. (2012). Az ápolás mint hivatás - Magatartástudományi elemzés. Szeged: JATEPress

Pikó, B. (1999). Munkahelyi stressz a nővérek körében: Kik a legveszélyeztetettebbek? Szenvedélybetegségek, 7(4), 272-281.

Pikó, B. (2003). Psychosocial work environment and psychosomatic health of nurses in Hungary. Work and Stress, 17(1), 93-100.

Pikó, B. (2006). Burnout, role conflict, job satisfaction and psychosocial health among Hungarian health care staff: A questionnaire survey. International Journal of Nursing Studies, 43(3), 311-318.

Purvanova, R.K., \& Muros, J.P. (2010). Gender differences in burnout: A meta-analysis. Journal of Vocational Behavior, 77(2), 168-185.

Salavecz, Gy., Neculai, K., \& Jakab, E. (2006). A munkahelyi stressz és az énhatékonyság szerepe a pedagógusok mentális egészségének alakulásában. Mentálhigiéné és Pszichoszomatika, 7(2), 95-109.

Schwarzer, R., Schmitz, G. S. \& Tang, C. (2000). Teacher burnout in Hong Kong and Germany: A cross-cultural validation of the Maslach Burnout Inventory. Anxiety, Stress, and Coping, 13(3), 309-326.

Seidman, S.A., \& Zager, J. (1991). A study of coping behaviours and teacher burnout. Work and Stress, 5(3), 205-216.

Skaalvik, E.M. \& Skaalvik, S. (2011). Teacher job satisfaction and motivation to leave the teaching profession: Relations with school context, feeling of belonging, and emotional exhaustion. Teaching and Teacher Education, 27, 1029-1038.

Szicsek, M. (2004). Kiégés és pszichológiai immunkompetencia összefüggései az ápolói munkában. Kharón, Thanatológiai Szemle, 8(1-2), 88-131.

Torma, B. (2013). Pedagóguspályák - Utak és lehetőségek a kiégés és szakmai kiteljesedés között. Alkalmazott Pszichológia, 3, 7-25.

Zinchenko, Y.P., Pervichko, E.I., \& Ostroumova, O.D. (2016). Burnout syndrome in patients with workplace hypertension. Rational Pharmacotherapy in Cardiology, 12(6), 675-680.

\section{Szerzói munkamegosztás}

Mihálka Mária: adatgyújtés megtervezése és lebonyolítása, elméleti áttekintés, statisztikai elemzés, kézirat elkészítése. Pikó Bettina: kutatástervezés ellenőrzése, statisztikai elemzés, kézirat végső formába öntése.

\section{Nyilatkozat érdekütközésról}

A szerzők ezúton kijelentik, hogy esetükben nem állnak fenn érdekütközések. 


\title{
Educators' satisfaction with life and its association with burnout and indicators of psychosomatic health
}

\author{
MIHÁLKA, MÁRIA - PIKÓ, BETTINA
}

Background: Educators' job is among the most stressful occupations, even among the helping professions. Burnout syndrome among them is also common and a great challenge since it may have many negative consequences, such as health problems, e.g., depression, or professional dissatisfaction. Aim: The main goal of the present study was to detect the role of burnout and other health-related variables (such as psychosomatic symptoms, health behavior and self-perceived health) in Hungarian educators' life satisfaction as an indicator of their well-being. Methods: Data were collected in a sample of Hungarian educators $(N=$ 2068, aged between 23-74 years, mean $=48.1$ years, and SD $=8.9$ years, $83.5 \%$ females) during the years of 2016-2017. Burnout was measured by Maslach Burnout Inventory Educators Survey. The questionnaire also included items on life satisfaction, psychosomatic symptoms and other health-related questions. Results: Results support that burnout is a real problem among Hungarian educators. Male and younger educators are especially at risk that may be explained by the lack of suitable routine to solve these problems. Among the burnout subscales, decreased personal accomplishment $(\beta=-.21, p<.001)$ and emotional exhaustion $(\beta=-.18, p<.001)$ play roles in life satisfaction. Satisfaction with life was also associated with psychosomatic symptoms $(\beta=-.14, p<.001)$ and one's own health evaluation $(\beta=.12, p<.001)$. Thus these health-related items also contributed to educators life satisfaction. Conclusions: Findings suggest that there is a great need of intervention programs to prevent burnout at both personal and organizational levels.

Keywords: burnout, satisfaction with life, educators, health behavior, psychosomatic symptoms 